\title{
RANCANG BANGUN SISTEM CERDAS PEMBERIAN NILAI OTOMATIS UNTUK UJIAN ESSAI MENGGUNAKAN ALGORITMA COSINE SIMILARITY
}

\author{
Hamdan Arfandy ${ }^{1}$, Izmy Alwiah Musdar ${ }^{2}$ \\ Informatika, STMIK KHARISMA Makassar ${ }^{1,2}$ \\ Email : hamdanarfandy@kharisma.ac.id ${ }^{1}$, izmyalwiah@kharisma.ac.id ${ }^{2}$
}

\begin{abstract}
ABSTRAK
Ujian merupakan salah satu cara evaluasi proses pembelajaran untuk mengetahui tingkat penguasaan peserta didik atas materi pengajaran yang diberikan. Secara garis besar terdapat dua jenis soal yang bisa digunakan yaitu soal objektif dan uraian. Pemberian nilai untuk jawaban soal uraian membutuhkan waktu yang lebih lama dibandingkan soal objektif karena harus diperiksa oleh orang yang benar-benar menguasai jawaban soal. Salah satu cara yang dapat digunakan untuk mempercepat pemeriksaan jawaban soal uraian adalah menggunakan sebuah sistem cerdas Automated Essay Scoring (AES). Automated Essay Scoring merupakan sistem penilaian soal ujian uraian secara otomatis dengan membandingkan kunci jawaban dengan jawaban yang diberikan peserta didik. Cosine Similarity merupakan algoritma yang dapat digunakan untuk mengukur kesamaan dua buah dokumen teks, seperti menghitung kesamaan antara dokumen kunci jawaban dan jawaban peserta ujian. Oleh karena itu, algoritma ini dapat digunakan untuk menghasilkan nilai otomatis untuk jawaban ujian essai. Tujuan penelitian ini adalah mengembangkan sebuah sistem ujian berbasis komputer dimana pada sistem ujian essay diberi nilai secara otomatis dengan memanfaatkan metode Cosine Similarity. Penelitian dilakukan dalam 4 tahapan yaitu spesifikasi kebutuhan, perancangan sistem, implementasi dan pengujian sistem. Hasil dari penelitian ini adalah algoritma Cosine Similarity telah berhasil diimplementasikan untuk memberikan nilai ujian essai secara otomatis pada sebuah sistem ujian berbasis komputer.
\end{abstract}

Kata Kunci: Ujian, Soal Uraian, AES, Cosine Similarity.

\begin{abstract}
Exam is one of the ways to evaluate student learning process to know their level of understanding in a teaching material. Basically, There are two types of exam questions. They are objective questions and essays. Grading essay questions takes more time than the objective questions because they have to be assessed by someone who trully understand the answer of the questions. One way of speeding up the assessement process is by using an Automated Essay Scoring (AES) System. Automated Essay Scoring is a system that can automatically yields grades for essay questions by measuring the similarity between the answer key and the student answers. Cosine similarity is an algorithm than can be used to measure the similarity between two text documents, for example measuring similarity between answer key and the student answers. Therefore, this algorithm can be applied to automatically generate score in essay questions. The aim of this study is to develop an computer-based test system which automatically grading the essay exam by applying Cosine similarity method. The research was conducted in 4 stages, namely requirements
\end{abstract}


specification, system design, system implementation and testing. The research result is cosine similarity algorithm has successfully implemented in computer-based test system for autograde essay question type.

Keywords: Exam, Essay, AES, Cosine Similarity

\section{PENDAHULUAN}

Ujian merupakan salah satu cara evaluasi proses pembelajaran untuk mengetahui tingkat penguasaan peserta didik atas materi pengajaran yang diberikan. Ujian dilakukan dengan memberikan soal terkait materi pembelajaran ke peserta didik untuk dijawab. Secara garis besar terdapat dua jenis soal yang bisa digunakan yaitu soal objektif dan uraian. Contoh soal objektif adalah soal berjenis pilihan ganda dan benar salah sedangkan contoh soal uraian adalah soal essay. Bentuk soal objektif relatif mudah dalam proses pemberian nilai karena jawaban soal jelas sehingga siapapun yang memeriksa akan memberikan penilaian yang sama (Susongko, 2013). Proses pemeriksaan soal jenis ini akan lebih mudah lagi apabila memanfaatkan teknologi komputer khususnya ujian berbasis computer basedtest (CBT). Sedangkan, pemberian nilai untuk jawaban soal uraian membutuhkan waktu yang lebih lama karena harus diperiksa oleh orang yang benar-benar menguasai materi soal (Susongko, 2013).

Proses pemberian nilai secara otomatis antara soal objektif dan uraian berbasis komputer dilakukan secara berbeda. Penerapan proses penilaian soal objektif lebih mudah dilakukan dengan bantuan komputer karena cukup mencocokkan kunci jawaban dengan jawaban yang diberikan peserta. Namun, bukan tidak mungkin melakukan penilaian untuk soal uraian menggunakan sistem komputer. Salah satu cara yang dapat digunakan adalah mengembangkan sebuah sistem cerdas Automated Essay Scoring (AES). Automated Essay Scroing merupakan sistem penilaian soal ujian uraian secara otomatis dengan membandingkan kunci jawaban dengan jawaban yang diberikan peserta didik dengan menghitung nilai kedekatan jawaban menggunakan algoritma-algoritma sistem cerdas (Pramukantoro, 2016).

Terdapat dua jenis algoritma yang dapat digunakan untuk menghitung kemiripan teks pada sistem penilaian otomatis. Algoritma yang berbasis String similarity dan corpus-based similarity. Algoritma yang termasuk dalam string similarity adalah cosine similarity sedangkan yang termasuk dalam corpusbased similarity adalah latent semantic analysis. Penelitian yang menggunakan pendekatan string similarity antara lain adalah penelitian yang menggunakan algoritma SVM dan menghasilkan penilaian yang mendekati dengan penilaian secara manual, yaitu sekitar 80-90\% (Febriyanto, 2019). Penelitian lain yang menggunakan pendekatan berbeda yaitu corpus-based similarity juga telah dilakukan. Algoritma yang digunakan adalah GLSA dengan tingkat kemiripan yang baik antara penilaian secara otomatis dan manual (Ruslan et al., 2018). Penelitian lain terkait juga dilakukan oleh Nurhayatin yang mengembangkan sistem 
penilaian jawaban soal uraian dengan menggunakan ukuran kemiripan semantik berdasarkan kamus yang disebut Machine Readable Dictionary (Hayatin, 2015).

Pada penelitian (Pramukantoro \& Fauzi, 2017) dilakukan perbandingan antara algoritma cosine similarity dan LDA dan hasil yang diperoleh adalah akurasi kedua algortima ini tidak terlalu berbeda namun algoritma cosine similarty memiliki waktu komputasi yang lebih cepat dalam mengukur kemiripan teks dibandingkan dengan metode corpus-based seperti LDA. Oleh karena itu, Pada penelitian ini dikembangkan sebuah sistem ujian berbasis komputer yang mampu melakukan penilaian soal ujian bertipe essai secara otomatis. Text processing digunakan untuk membersihkan dokumen kunci jawaban dan jawaban peserta ujian. Metode pembobotan Tf-Idf digunakan untuk pembobotan term dan algoritma cosine similarity digunakan untuk mengukur kemiripan kunci jawaban dan jawaban peserta ujian. Nilai hasil ujian ditentukan berdasarkan hasil perhitungan cosine similarity.

\section{LANDASAN TEORI}

2.1.Computer-based Test

$$
\text { Computer-based test }
$$

merupakan ujian yang dilaksanakan dengan memanfaatkan teknologi informasi dan komputer. Computer-based test lebih efisien dibandingkan dengan ujian secara konvensional. Ujian konvensional yang dimaksud adalah ujian yang menggunakan kertas dan pulpen. Ujian konvensional memiliki beberapa kelemahan antara lain rawan tidak kecurangan, membutuhkan waktu untuk mempersiapkan soal ujian, hasil ujian biasanya lama diperoleh (Arisandi et al., 2018).
Proses penilaian jawaban soal ujian CBT akan mudah diperoleh jika soal bertipe pilihan ganda. Jawaban bersifat pasti sehingga penilaian dapat dilakukan cukup dengan mencocokan jawaban yang diinput ke sistem CBT dengan jawaban dari peserta ujian. Hal ini akan berbeda jika tipe soal adalah uraian. Tipe soal seperti ini memiliki jawaban yang lebih bervariasi dari peserta ujian sehingga penilaian jawaban tidak memiliki pola yang pasti.

\subsection{Automated Essay Scoring}

Penilaian soal uraian secara otomatis dengan menggunakan teknologi komputer dapat dilakukan dengan menggunakan teknologi Automated Essay Scoring (AES). Penilaian AES diperoleh dengan menghitung kemiripan teks antara kunci jawaban dan jawaban peserta ujian. Terdapat tiga metode untuk mengukur kemiripan teks yaitu Corpus-Based Similarity, String-Based Similarity, dan Knowledge-Based Similarity (Gomaa \& Fahmy, 2014). Corpus-Based Similarity adalah metode menghitung kemiripan teks dengan mempertimbangkan kesamaan makna melalui kamus (Pramukantoro, 2016). String-Based Similarity adalah metode menghitung kemiripan teks dengan mencocokkan kata dalam dua buah dokumen teks (Gomaa \& Fahmy, 2012). Sedangkan Knowledge-Based Similarity adalah metode menghitung kemiripan teks dengan menghitung derajat kemiripan antar kata menggunakan jaringan semantik. Contoh jaringan semantik yang umum digunakan adalah WordNet (Gomaa \& Fahmy, 2014).

Peta jalan penelitian sistem penelitian ujian uraian otomatis ditunjukkan pada Gambar 1. Pada Gambar 1 diuraikan 
penelitian dalam bidang ini dalam tiga tahun terakhir yaitu 2016 sampai 2018. Metode pengukuran kemiripan teks yang umum digunakan dalam tidak tahun terkahir adalah String-Based Similarity dan Corpus-Based Similarity. Secara garis besar perkembangan penelitian terkait penilaian ujian uraian otomatis adalah pada preprocessing dokumen teksnya. Pada tahun 2017 terdapat beberapa penelitian yang memanfaatkan teknik preprocessing dasar seperti stemming. Sedangkan pada tahun 2018 terdapat penelitian yang menggunakan lebih banyak lagi teknik preprocessing yaitu tokenisasi, stopword removal dan stemming.
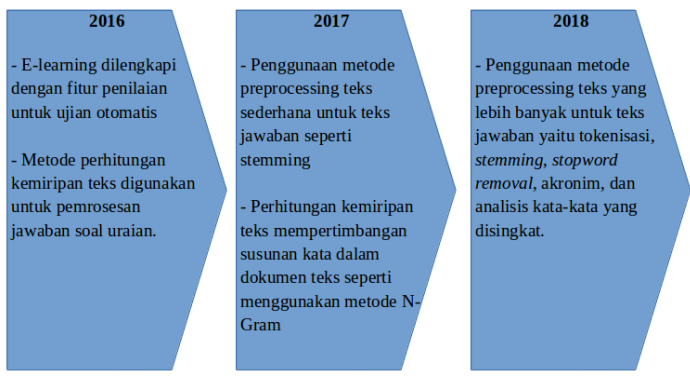

Gambar 1. Peta Jalan Penelitian Sistem Penilaian Ujian Uraian Otomatis

Berikut uraian singkat penelitian terkait penilaian otomatis jawaban soal ujian uraian yang dilakukan dalam tiga tahun terakhir :

1. Pramukantoro (2016) melakukan penelitian dengan mengembangankan sistem penilaian otomatis jawaban uraian pendek pada E-learning belajardisini.com (Pramukantoro, 2016). Penelitian ini mengintegrasikan cosine similarity ke e-learning untuk diukur performanya di server.

2. Fauzi dkk (2017) melakukan penelitian sistem penilaian ujian uraian otomatis menggunakan N-Gram dan Cosine
Similarity Untuk E-learning berbasis Gamification (Fauzi et al., 2017). Penelitian ini mengembangakan sebuah E-learning berbasis Gamification yang memiliki fitur koreksi otomatis pada ujian dengan jenis soal uraian. Penelitian ini tidak hanya memperhitungkan kesamaan kata dalam teks jawaban tetapi juga urutan katanya. Oleh karena itu, selain menggunakan algoritma Cosine Similarity juga digunakan Metode N-Gram.

3. Rinartha (2017) melakukan penelitian dengan mengembangkan sistem penilaian ujian untuk jenis soal uraian dengan menerapkan metode preprocessing teks (Rinartha, 2017). Metode preprocessing teks yang digunakan adalah stemming. Stemming merupakan metode untuk mengekstrak kata dasar pada dokumen teks. Metode perhitungan kemiripan teks yang digunakan dalam penelitian ini adalah Cosine Similarity.

4. Ruslan dkk (2018) melakukan penelitian dengan mengembangkan sebuah aplikasi untuk membantu melakukan penilaian pada jawaban ujian uraian dengan memanfaatkan algoritma yang tergolong dalam Corpus-Based Similarity (Ruslan et al., 2018). Penelitian ini menggunakan Algoritma Generalized Latent Semantic Analysis (GLSA). Preprocessing dilakukan pada dokumen teks jawaban. Preprocessing yang gunakan adalah tokenisasi, stopword removal, tokenisasi dan term weight.

5. Prastowo dkk (2018) melakukan penelitian dengan mengusulkan sebuah framework untuk pemrosesan jawaban soal uraian secara otomatis berbasis komputasi (Prastowo et al., 2018). 
Framework yang dikembangkan menerapkan preprocessing dokumen teks yaitu stopword removal, stemming, koreksi kesalahan penulisan, akronim, dan analisis kata-kata yang disingkat sebagai proses awal. Proses selanjutnya adalah mengukur kemiripan teks, kemudian langkah terkahir proses klasifikasi untuk menentukan bobot nilai dari jawaban ujian uraian. literatur mencakup kajian teori dan hasil penelitian terdahulu dituliskan sebagai bagian terpisah.

Terdapat beberapa penelitian yang telah dilakukan terkait dengan sistem penilaian ujian essai secara otomatis. Adapun perbedaan antara penelitian yang dilakukan sebelumnya adalah pengukuran kemiripan jawaban ujian dengan kunci jawaban penelitian ini menggunakan pendekatan string-based similairty berbeda dengan penelitian (Fauzi et al., 2017), (Rinartha, 2017) dan (Ruslan et al., 2018) yang menggunakan pendekatan corpusbased. Selain itu, penelitian ini tidak bertujuan untuk membuat framework seperti penelitian (Prastowo et al., 2018) atau mengukur perfomansi algoritma pada server (Pramukantoro, 2016) namun mengembangkan sebuah sistem ujian essai berbasis web dengan memanfaatkan cosine similairty agar sistem ujian berbasis komputer memiliki kemampuan memberikan nilai secara otomatis.

\section{METODE PENELITIAN}

Tahapan penelitian terdiri dari 4 proses. Tahapan penelitian ditunjukkan pada Gambar 2. Penelitian dimulai dengan proses penentuan kebutuhan sistem kemudian berturut-turut dilanjutkan ke tahap perancangan sistem, implementasi dan pengujian. Berikut ini uraian tentang tahapan penelitian :

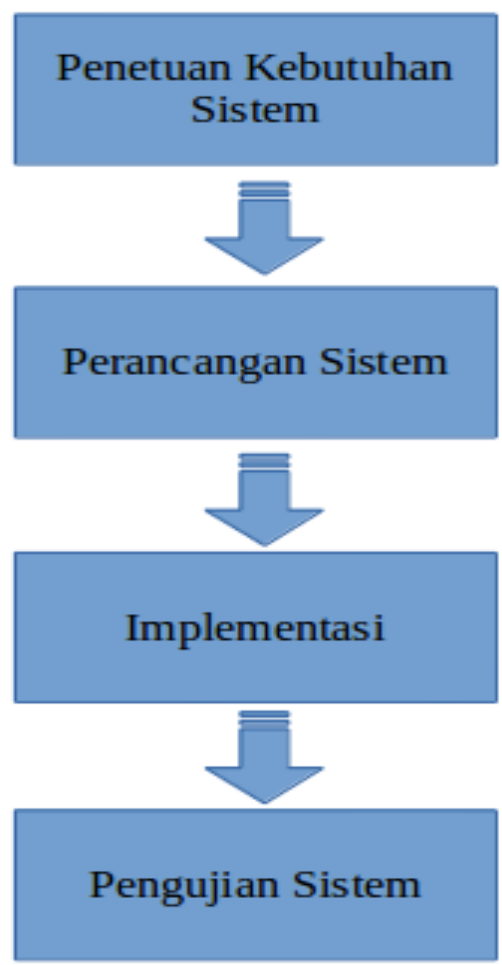

Gambar 2. Tahapan Penelitian

\subsection{Penentuan Kebutuhan Sistem}

Penentuan kebutuhan sistem merupakan salah satu tahap penting dalam pengembangan perangkat lunak. Spesifikasi kebutuhan merupakan deskripsi tentang layanan yang tersedia pada sistem dan batasan-batasan operasi pada sistem. Studi literatur dilakukan untuk menyusun kebutuhan sistem. Studi literatur bertujuan untuk mengumpulkan informasi terkait dengan kebutuhan sistem menyangkutan pengolahan dokumen teks. Selain itu untuk memperoleh gambaran kebutuhan pengguna terkait pengembangan sistem computer-based test dengan penilaian dilakukan secara otomatis maka dilakukan pengamatan pada 
proses ujian berbasis komputer pada BPSDM Sulawesi Selatan.

Berdasarkan kebutuhan pengguna dan studi literatur tentang pemrosesan teks maka disusun spesifikasi kebutuhan untuk sistem penilaian ujian essai otomatis sebagai berikut :

1) Pengguna (Pengajar dan Peserta Ujian) memiliki akun berupa username dan password untuk dapat login ke sistem.

2) Pengajar menginputkan soal dan kunci jawaban soal ke sistem.

3) Pengajar dapat menyetel durasi ujian.

4) Nilai ujian tampil sesaat setelah peserta ujian menyelesaikan ujiannya.

5) Terdapat proses preprocessing text untuk membersihkan dokumen teks, yaitu kunci jawaban dan jawaban perserta ujian.

6) Preprocessing text berupa proses case folding, tokenization, stopword removal dan stemming.

7) Sistem melakukan pembobotan teks menggunakan metode Tf-Idf.

8) Sistem menghitung kemiripan jawaban peserta dengan kunci jawaban menggunakan ukuran kemiripan Cosine Similarity.

9) Hasil ujian merupakan konversi dari nilai Cosine Similarity menjadi nilai ujian dengan skala 0-100.

10) Sistem menggunakan database MySQL untuk penyimpanan data sistem.

11) Sistem yang dikembangkan berbasis web.

\subsection{Perancangan Sistem}

Rancangan proses pada sistem penilaian ujian otomatis digambarkan menggunakan diagram alur. Diagram alur ditunjukkan pada Gambar 3. Proses yang pertama adalah tahap preprocessing terhadap kunci jawaban dan jawaban. Proses kedua adalah perhitungan bobot dari kunci jawaban dan jawaban dari peserta ujian. Proses ketiga adalah perhitungan nilai kesamaan antara kunci jawaban dan jawaban dari peserta ujian menggunakan perhitungan kemiripan Cosine Similarity. Kemudian langkah terakhir adalah penentuan nilai dari jawaban peserta ujian berdasarkan nilai hasil perhitungan kemiripan. Tahapan dalam preprocessing text ditunjukkan pada Gambar 4.

Preprocessing text merupakan serangkaian proses yang diterapkan pada dokumen teks sebelum dilakukan perhitungan kemiripan. Tahap ini dilakukan untuk membersihkan dokumen teks sehingga diperoleh kata-kata yang penting dan kata-kata yang tidak terlalu berpengaruh tidak dimasukkan dalam proses selanjutnya. Proses dimulai dengan case folding. Tahap ini mengubah dokumen teks menjadi huruf kecil. Tahap tokenizing merupakan tahap mengubah dokumen teks menjadi kumpulan kata-kata serta menghilangkan tanda baca seperti titik(.), koma(,), dsb. Tahap selanjutnya adalah Stopword Removal yaitu menghilangkan kata-kata yang tidak terlalu bermakna, seperti "yang”, "bahwa", "dan", "atau", dsb. Langkah terakhir adalah mengubah kata yang memiliki imbuhan menjadi kata dasarnya melalui proses stemming. Setelah melewati 4 tahap preprocessing maka diperoleh teks kunci jawaban dan jawaban yang sudah bersih dan dalam bentuk kumpulan kata. 


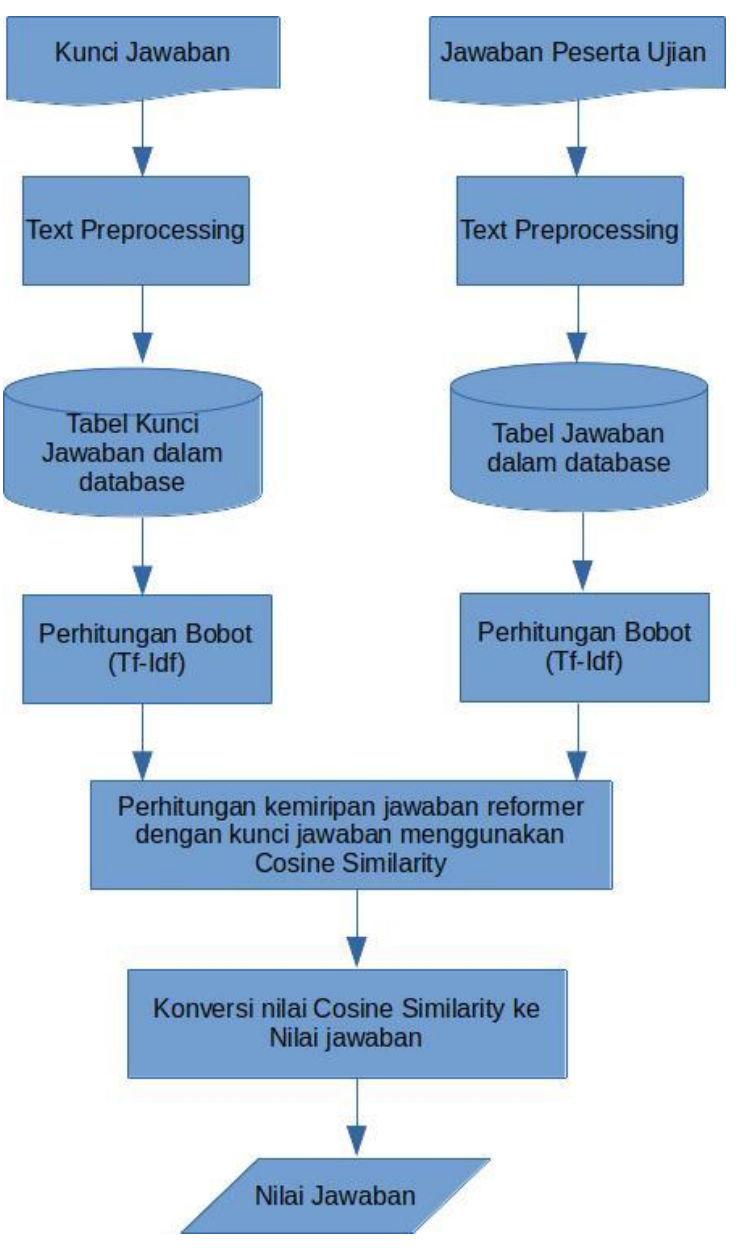

Gambar 3. Alur Proses Sistem Penilaian Ujian Essai

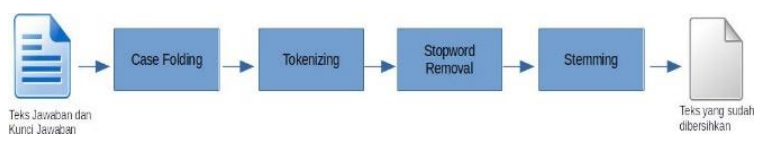

Gambar 4. Preprocessing Text

Setiap teks jawaban maupun kunci jawaban akan dihitung bobotnya. Salah satu metode perhitungan pembobotan teks adalah Tf-Idf. Pembobotan teks melalui Tf-Idf didasarkan pada perbandingan frekuensi kemunculan suatu kata dalam sebuah dokumen teks dan banyaknya dokumen yang mengandung kata tersebut. Perhitungan bobot dengan Tf-Idf dilakukan dengan menggunakan Persamaan (1).

$\mathrm{w}(\mathrm{t}, \mathrm{d})=\mathrm{tf}(\mathrm{t}, \mathrm{d}) * \log (\mathrm{N} /(\mathrm{df}(\mathrm{t})+1))$
Dimana :

$\mathrm{t}:$ term (kata)

d : dokumen

$\mathrm{w}(\mathrm{t}, \mathrm{d})$ : bobot term $\mathrm{t}$ pada dokumen $\mathrm{d}$

$\operatorname{tf}(\mathrm{t}, \mathrm{d})$ : jumlah term $\mathrm{t}$ pada dokumen $\mathrm{d} /$ jumlah kata pada dokumen $\mathrm{d}$

$\mathrm{N}$ : Jumlah seluruh dokumen

$\mathrm{df}(\mathrm{t})$ : Jumlah dokumen yang mengandung term $\mathrm{t}$

Cosine Similarity merupakan salah satu metode pengukuran kemiripan antara dua dokumen teks. Cosine similarity digunakan untuk mengukur kemiripan antara jawaban peserta ujian dan kunci jawaban. Skala nilai kemiripan dari metode ini adalah 0-1. Semakin mendekati 1 maka kemiripan jawaban peserta ujian dan kunci jawaban semakin tinggi yang berarti nilai kebenaran jawaban semakin tinggi, begitupun sebaliknya, semakin mendekati 0 nilai kemiripan maka kecocokan jawaban peserta ujian dengan kunci jawaban semakin rendah. Formula untuk penentuan nilai kemiripan menggunakan cosine similarity ditunjukkan pada Persamaan (2).

$$
\text { similarity }=\cos (\theta)=\frac{\sum_{i=1}^{n} A_{i} B_{i}}{\sqrt{\sum_{i=1}^{n} A_{i}^{2}} \sqrt{\sum_{i=1}^{n} B_{i}^{2}}}
$$

Dimana :

Ai : Bobot term i pada dokumen jawaban

Bi : Bobot term i pada dokumen kunci jawaban

$\mathrm{n}$ : Banyaknya term

Nilai dari jawaban ujian peserta ujian diperoleh dari konversi nilai Cosine Similarty menjadi nilai dengan skala 0100. Proses tata cara konversi nilai Cosine Similarity menjadi nilai hasil ujian menggunakan Persamaan (3). 


$$
\text { Nilai Ujian }=\frac{\sum_{i=1}^{n} J_{i}}{n} \times 100
$$

Dimana :

J : Nilai Cosine Similarity jawaban soal dengan kunci jawaban

$\mathrm{n}$ : Jumlah Soal

\subsection{Implementasi}

Implementasi adalah menerjemahkan hasil rancangan ke dalam bentuk kode program. Sistem yang akan dikembangkan merupakan sistem berbasis web sehingga digunakan bahasa pemrograman HTML, PHP, CSS dan Javascript. Sedangkan untuk menyimpan data digunakan database MySQL. Ketua Peneliti yang bertanggung jawab pada proses implementasi.

\section{Pengujian Sistem}

Proses pengujian sistem dilakukan untuk memvalidasi semua fitur dalam system telah mengeluarkan keluarkan yang sesuai dengan input yang diberikan.

\section{HASIL DAN PEMBAHASAN}

Berdasarkan kebutuhan fungsional dari sistem maka hasil pengembangan sistem adalah sebagai berikut :

\subsection{Pembuatan Akun Peserta Ujian}

Tampilan halaman pembuatan akun peserta ujian ditunjukkan pada Gambar 5. Terdapat empat buah data yang perlu diiskan. Apabila akun berhasil dibuat maka data peserta ujian akan tampil pada halaman daftar pengguna yang ditunjukkan pada Gambar 6.

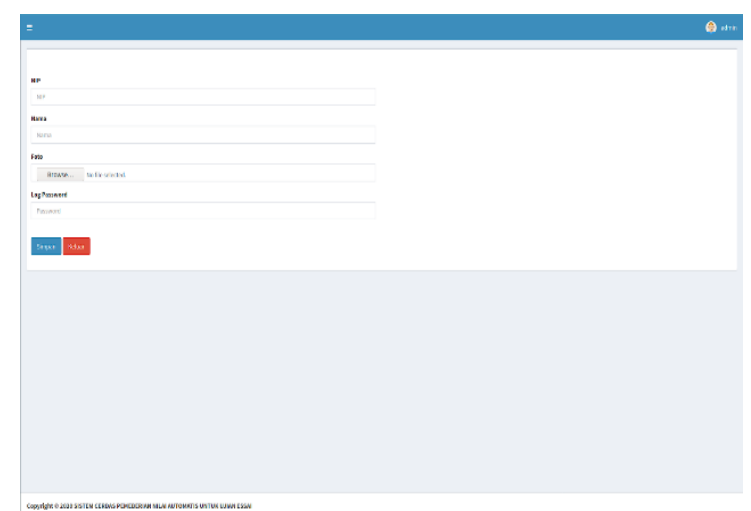

Gambar 5. Halaman Tambah Pengguna

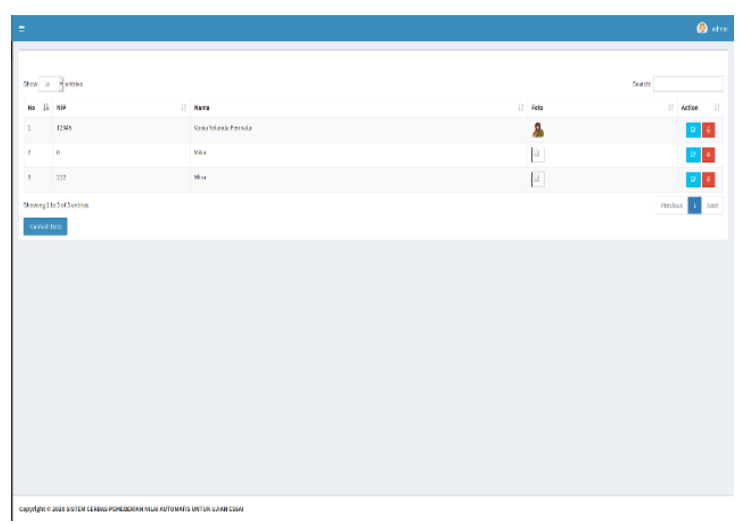

Gambar 6. Halaman Daftar Pengguna

\subsection{Halaman Input Soal dan Kunci Jawaban}

Spesifikasi kebutuhan sistem untuk penginputan soal dan kunci jawaban oleh pengajar diimplementasikan melalui halaman soal ujian. Halaman soal ujian ditunjukkan pada Gambar 7. Terdapat tombol Tambah Data untuk memasukkan soal ujian beserta kunci jawabannya. Terdapat tombol mengubah atau menghapus soal ujian pada kolom Action. Setelah semua soal dan kunci jawaban untuk ujian dimasukkan, maka pengajar perlu menekan tombol Proses Data. Ini akan menjalankan proses preprocessing hingga pembobotan teks kunci jawaban. 


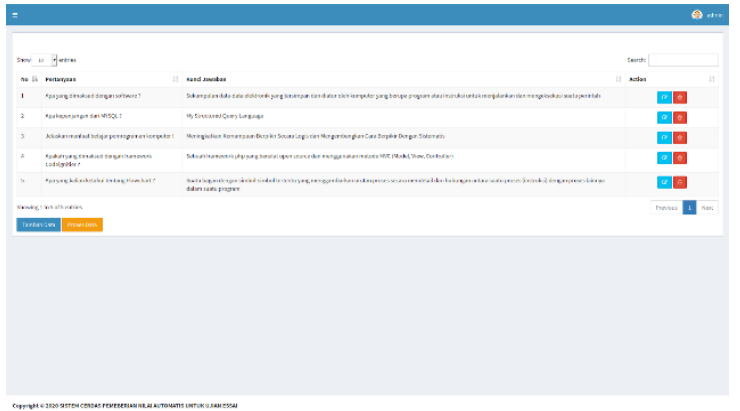

Gambar 7. Halaman Soal Ujian

Pengajar perlu menyetel durasi ujian. Penginputan durasi ujian diimplementasikan pada halaman waktu ujian. Pengajar menginputkan durasi ujian dalam satuan menit. Setelah memasukkan lama ujian maka pilih tombol Simpan. Tampilan halaman untuk mengatur durasi ujian ditunjukkan pada Gambar 8.

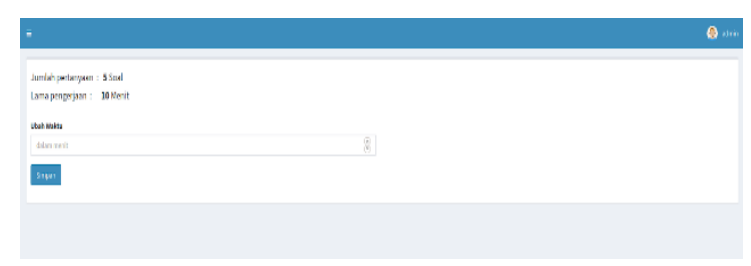

Gambar 8. Halaman Durasi Ujian

\subsection{Halaman Pengerjaan Ujian}

Sistem menyediakan fitur ujian pada halaman pengerjaan ujian. Ketika peserta ujian login ke sistem untuk mengikuti ujian, maka tampil halaman awal yang memuat infomasi petunjuk ujian termasuk informasi tentang durasi ujian. Tampilan halaman awal tersebut ditunjukkan pada Gambar 9.

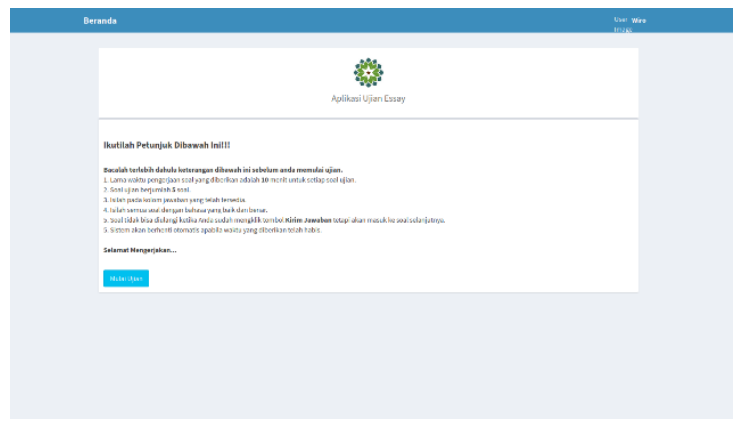

Gambar 9. Halaman Awal Pelaksanaan Ujian
Soal ujian tampil satu persatu dan secara acak. Sehingga susunan soal untuk setiap peserta tidak sama. Tampilan soal ujian ditunjukkan pada Gambar 10. Setelah peserta ujian mengisikan jawaban, pilih tombol Kirim Jawaban, maka jawaban tersebut diproses dan tersimpan dan tampilan ujian akan beralih ke soal berikutnya. Sistem tidak memungkinkan pengulangan soal ujian. Ketika peserta sudah mengirimkan jawabannya maka ia tidak bisa lagi kembali ke soal tersebut untuk mengubah jawabannya. Ketika waktu ujian telah habis atau peserta telah menyelesaikan ujiannya, maka akan tampil halaman ujian selesai dan hasil ujian yang ditunjukkan masing-masing pada Gambar 11 dan Gambar 12.

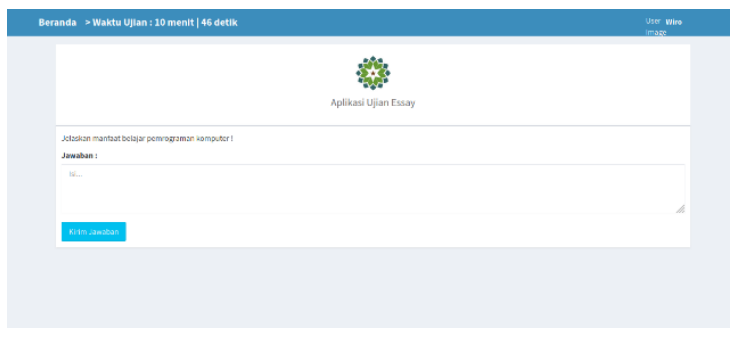

Gambar 10. Halaman Soal Ujian

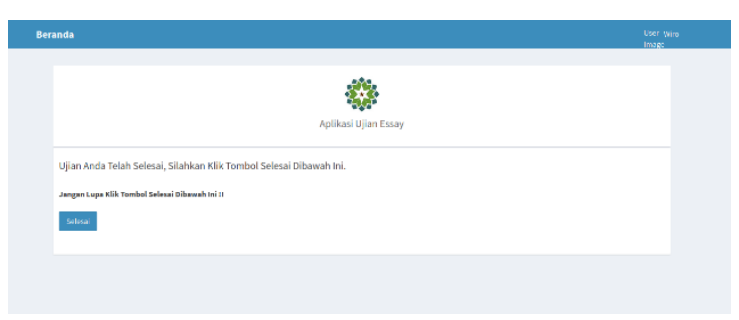

Gambar 11. Halaman Ujian Selesai

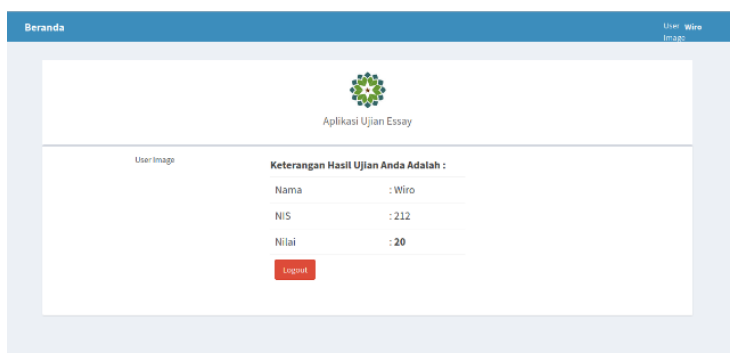

Gambar 12. Halaman Hasil Ujian 


\subsection{Nilai Cosine Similarity}

Nilai cosine similarity merupakan nilai yang menunjukkan tingkat kemiripan jawaban peserta ujian dan kunci jawaban. Pada sistem yang dikembangkan terdapat tampilan untuk melihat nilai cosine similarity dari jawaban peserta ujian. Halaman ini hanya bisa dilihat oleh pengguna dengan status admin. Tampilan dari halaman rincian penilaian ini ditunjukkan pada Gambar 13.

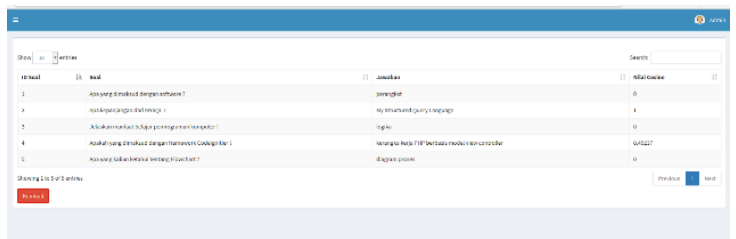

Gambar 13. Halaman Rincian Penilaian

Nilai cosine similarity diperoleh dengan terlebih dahulu melakukan preprocessing text untuk dokumen jawaban dan kunci jawaban. Misal untuk contoh pertanyaan berikut :

Soal 1 : Apa yang dimaksud dengan perangkat lunak?

Soal 2: Apakah yang dimaksud dengan framework Codeignitier?

Kunci jawaban dan jawaban perserta ujian yang dari soal tersebut ditunjukkan pada Tabel 1.

Tabel 1. Kunci Jawaban dan Jawaban Peserta Ujian

\section{No Kunci Jawaban Jawaban peserta ujian}

1 Sekumpulan data- Sekumpulan data elektronik yang instruksitersimpan dan diatur instruksi yang oleh komputer yang dijalankan oleh berupa program atau komputer untuk instruksi untuk menjalankan menjalankan dan fungsi mengeksekusi suatu

perintah

2 Sebuah framework framework PHP php yang bersifat yang openopen source dan source dan menggunakan menerapkan metode MVC model view (Model, View, control (MVC) Controller)

Hasil preprocessing text untuk kunci jawaban dan jawaban peserta ujian ditunjukkan pada Tabel 2 dan Tabel 3.

Tabel 2. Hasil Preprocessing Text Kunci Jawaban

\begin{tabular}{cl}
\hline Soal & \multicolumn{1}{c}{ Term } \\
\hline 1 & $\begin{array}{l}\text { kumpul, elektronik, simpan, } \\
\text { atur, komputer, rupa, } \\
\text { program, instruksi, jalan, } \\
\text { eksekusi, perintah }\end{array}$ \\
2 & $\begin{array}{l}\text { framework, php, sifat, open, } \\
\text { source, guna, metode, mvc, } \\
\text { model, view, controller }\end{array}$ \\
\hline
\end{tabular}

Tabel 3. Hasil Preprocessing Text Jawaban Peserta Ujian

\begin{tabular}{cl}
\hline Soal & \multicolumn{1}{c}{ Term } \\
\hline 1 & $\begin{array}{l}\text { kumpul, Instruksi, instruksi, } \\
\text { jalan, jalan, komputer, fungsi }\end{array}$ \\
2 & $\begin{array}{l}\text { framework, php, open, source, } \\
\text { terap, model, view, control, } \\
\text { mvc }\end{array}$ \\
\hline
\end{tabular}

Setelah melakukan preprocessing teks, maka selanjutnya setiap kata dihitung bobotnya menggunakan formula tf-idf. Misalkan perhitungan bobot kata 'kumpul' pada kunci jawaban soal 1 sebagai berikut 


$$
\begin{aligned}
\mathrm{w}(\text { kumpul, } \mathrm{kj} 1) & =\mathrm{tf}(\mathrm{t}, \mathrm{d}) * \log (\mathrm{N} / \mathrm{df}) \\
= & * \log (2 / 1) \\
= & 1 * 0.30103 \\
= & 0.301
\end{aligned}
$$

Hasil pembobotan term ditunjukkam pada Tabel 4 dan Tabel 5.

Tabel 4. Pembobotan Tf-Idf Kunci Jawaban

\begin{tabular}{|c|c|c|c|}
\hline Term & tf & idf & tf-idf \\
\hline & 1 & 0.30103 & 0.30103 \\
\hline ksi & 2 & 0.30103 & 0.60206 \\
\hline jalan & 2 & 0.30103 & 0.60206 \\
\hline komputer & 1 & 0.30103 & 0.30103 \\
\hline fungsi & 1 & 0.30103 & 0.30103 \\
\hline fram & 1 & 0.30103 & 0.30103 \\
\hline php & 1 & 0.30103 & 0.30103 \\
\hline open & 1 & 0.30103 & 0.30103 \\
\hline source & 1 & 0.30103 & 0.30103 \\
\hline terap & 1 & 0.30103 & 0.30103 \\
\hline model & 1 & 0.30103 & 0.30103 \\
\hline view & 1 & 0.30103 & 0.30103 \\
\hline control & 1 & 0.30103 & 0.30103 \\
\hline $\mathrm{mvc}$ & 1 & 0.30103 & 0.30103 \\
\hline \multicolumn{4}{|c|}{$\begin{array}{l}\text { Selanjutnya adalah perhitungan nilai } \\
\text { kemiripan jawaban dengan kunci jawaban } \\
\text { menggunakan cosine similarity. } \\
\text { Perhitungan kemiripan jawaban soal } 1 \\
\text { (JS1) dan kunci jawaban soal } 1 \text { (KJ1) } \\
\text { adalah: }\end{array}$} \\
\hline \multicolumn{4}{|c|}{$\begin{array}{l}\text { dot product }(\mathrm{JS} 1, \mathrm{KJ} 1)=0.30103 * 0 \\
0.30103+0.60206 * 0.30103+0.60206^{*} \\
0.30103+0.30103 * 0.30103=0.54371\end{array}$} \\
\hline \multicolumn{4}{|c|}{$\begin{aligned}\|\mathrm{JS} 1\| & =\sqrt{ } 0.30103^{2}+0.60206^{2}+\ldots+0.30103^{2} \\
& =0.9984\end{aligned}$} \\
\hline \multicolumn{4}{|c|}{$\begin{aligned}\|\mathrm{KJ} 1\| & =\sqrt{ } 0.30103^{2}+0.30103^{2}+\ldots+0.30103^{2} \\
& =0.9984\end{aligned}$} \\
\hline \multicolumn{4}{|c|}{ Similarity $(\mathrm{JS} 1, \mathrm{KJ} 1)=$} \\
\hline \multicolumn{4}{|c|}{$\operatorname{dot}$ product $(\mathrm{JS} 1, \mathrm{KJ} 1) /\|\mathrm{JS} 1\|^{* *} \mid \mathrm{KJ} 1 \|$} \\
\hline \multicolumn{4}{|c|}{$=0.54371 /(0.9984 * 0.9984)$} \\
\hline & & & \\
\hline
\end{tabular}

\begin{tabular}{lccc}
\hline \multicolumn{1}{c}{ Term } & tf & idf & tf-idf \\
\hline kumpul & 1 & 0.30103 & 0.30103 \\
elektronik & 1 & 0.30103 & 0.30103 \\
simpan & 1 & 0.30103 & 0.30103 \\
atur & 1 & 0.30103 & 0.30103 \\
komputer & 1 & 0.30103 & 0.30103 \\
rupa & 1 & 0.30103 & 0.30103 \\
program & 1 & 0.30103 & 0.30103 \\
instruksi & 1 & 0.30103 & 0.30103 \\
jalan & 1 & 0.30103 & 0.30103 \\
eksekusi & 1 & 0.30103 & 0.30103 \\
perintah & 1 & 0.30103 & 0.30103 \\
framework & 1 & 0.30103 & 0.30103 \\
php & 1 & 0.30103 & 0.30103 \\
sifat & 1 & 0.30103 & 0.30103 \\
open & 1 & 0.30103 & 0.30103 \\
source & 1 & 0.30103 & 0.30103 \\
guna & 1 & 0.30103 & 0.30103 \\
metode & 1 & 0.30103 & 0.30103 \\
mvc & 1 & 0.30103 & 0.30103 \\
model & 1 & 0.30103 & 0.30103 \\
view & 1 & 0.30103 & 0.30103 \\
controller & 1 & 0.30103 & 0.30103 \\
\hline & & & \\
\hline
\end{tabular}

Tabel 5. Pembobotan Tf-Idf Jawaban Peserta Ujian : 
Perhitungan kemiripan jawaban soal 2 (JS2) dan kunci jawaban soal 2 (KJ2) adalah :

dot product $(\mathrm{JS} 2, \mathrm{JK} 2)=0.30103 * 0$

$0.30103+0.30103 * 0.30103+\ldots+$

$0.30103 * 0.30103=0.6343$

$$
\begin{aligned}
\|\mathrm{JS} 2\| & =\sqrt{ } 0.30103^{2}+0.30103^{2}+\ldots+0.30103^{2} \\
& =0.9984 \\
\|\mathrm{KJ} 2\| & =\sqrt{ } 0.30103^{2}+0.30103^{2}+\ldots+0.30103^{2} \\
& =0.9031
\end{aligned}
$$

Similarity $(\mathrm{JS} 2, \mathrm{KJ} 2)=$

dot product (JS2, KJ2) / \|JS2 $\|*\| \mathrm{KJ} 2 \|$

$=0.6343 /(0.9984 * 0.9031)$

$=0.7035$

Perhitungan nilai hasil ujian untuk kasus di atas adalah sebagai berikut :

Nilai Ujian $=(($ Similarity $(\mathrm{JS} 1, \mathrm{KJ} 1)+$

Similarity $(\mathrm{JS} 2, \mathrm{KJ} 2)) /$ jumlah soal $) * 100$

$$
\begin{aligned}
& =((0.5454+0.7035) / 2) * 100 \\
& =62
\end{aligned}
$$

Maka diperoleh nilai ujian untuk penilaian otomatis menggunakan cosine similarity adalah 62 .

\section{E. Pengujian Fungsional}

Test case pada pengujian fungsional didasarkan pada spesifikasi kebutuhan sistem.

Tabel 6. Hasil Pengujian Fungsional

\begin{tabular}{ll}
\hline Test Case & Hasil pengujian \\
\hline Apakah & Berhasil, pengguna \\
pengguna dapat & yang berstatus admin \\
login ke sistem? & dapat mengakses \\
& halaman utama admin \\
& , sedangkan pengguna \\
& sebagai peserta ujian \\
& menampilkan \\
& halaman informasi
\end{tabular}

$$
\text { petunjuk ujian }
$$

Apakah pengajar Berhasil, soal dan bisa menginput kunci jawaban soal dan kunci berhasil ditampilkan jawaban? pada halaman soal

Apakah pengajar Berhasil, pengajar bisa membatasi bisa menyetel waktu waktu ujian? ujian dalam satuan menit dan ujian akan berkahir sesuai dengan waktu yang ditentukan

Apakah sistem Berhasil, kunci mampu jawaban dan jawaban melakukan peserta berhasil preprocessing ditokenisasi, text untuk dihilangkan imbuhan jawaban dan akhiran dan kunci jawaban? awalannya, serta dihilangkan kata-kata yang tidak terlalu bermakna.

Apakah sistem Berhasil, bobot tf-idf mampu kata hasil melakukan preprocessing pembobotan tersimpan dalam basis kata dengan tf- data idf?

Apakah sistem Berhasil, nilai cosine mampu similarity dari sistem menghitung yang dikembangkan cosine sama dengan hasil similarity? perhitungan yang dilakukan secara manual.

Apakah sistem Berhasil, sistem berhasil berhasil menampilkan memberikan nilai perserta ujian nilai secara secara ototamis pada otomatis? saat peserta ujian telah berhasil menyelesaikan ujian atau pada saat waktu ujian telah habis. 
Nilai yang diperoleh merupakan konversi dari nilai cosine similarity dengan skala 0-100.

Pengujian juga dilakukan untuk
menghitung similarity apabila terdapat
kata negasi ,misalnya kata tidak, pada
jawaban. Pada contoh soal sebelumnya,
untuk jawaban soal nomor 2 diubah dari
'menerapkan' menjadi 'tidak menerapkan'.
Namun, nilai kemiripan menunjukkan
hasil yang sama pada jawaban yang
terdapat kata negasi dan tidak terdapat
negasi. Hal ini karena term yang
digunakan adalah per-kata (unigram),
sehingga kata negasi tidak dianggap satu
kesatuan dengan kata setelahnya.

\section{SIMPULAN DAN SARAN}

Berdasarkan penelitian yang telah dilakukan maka dapat ditarik kesimpulan sebagai berikut :

a) Pada penelitian ini telah berhasil dirancangan dan diimplementasikan sebuah sistem ujian essai berbasis web yang mampu meberikan penilaian secara otomatis untuk ujian dengan memanfaatkan metode cosine similarity.

b) Sistem yang dikembangkan berhasil menerapkan preprocessing text dan menghitung bobot teks menggunakan Tf-Idf. Nilai Cosine Similarity untuk setiap jawaban berhasil ditampilkan dan berhasil dikonversi menjadi nilai hasil ujian.

c) Perhitungan nilai secara otomatis dengan cosine similarity kurang efektif apabila terdapat negasi pada jawaban atau jawaban pertanyaan menggunakan sinonim kata dari kunci jawaban.

Saran untuk penelitian selanjutnya adalah menggabungkan antara unigram dan bigram dalam perhitungan cosine similarity untuk mengatasi ketidakefektifan perhitungan cosine similarity apabila terdapat kata negasi dalam dokumen teks.

\section{UCAPAN TERIMA KASIH}

Peneliti mengucapkan terima kasih kepada Kemeristekdikti sebagai pihak yang telah mendanai penelitian ini.

\section{DAFTAR PUSTAKA}

Arisandi, D., Rachmawati, D., \& Aulia, I. (2018). Pengembangan ComputerBased Test sebagai Strategi Peningkatan Efisiensi Evaluasi Kegiatan Belajar Mengajar. Jurnal Insitusi Politeknik Ganesha Medan, 1(1), 1-8.

Fauzi, M. A., Utomo, D. C., Pramukantoro, E. S., \& Setiawan, B. D. (2017). Automatic essay scoring system using N-GRAM and cosine similarity for gamification based elearning. ACM International Conference Proceeding Series, Part F1312, 151-155. https://doi.org/10.1145/3133264.3133 303

Febriyanto, F. (2019). Sistem Penilaian Otomatis Jawaban Esai Dengan Menggunakan Metode Vector Space Model Pada Beberapa Perkuliahan Di Stmik Indonesia Banjarmasin. Jurnal Teknologi Informasi, XIV(1), 53-68.

Gomaa, W. H., \& Fahmy, A. A. (2012). Short Answer Grading Using String 
Similarity And Corpus-Based Similarity. International Journal of Advanced Computer Science and Applications, 3(11), 115-121. https://doi.org/10.14569/ijacsa.2012.0 31119

Gomaa, W. H., \& Fahmy, A. A. (2014). Automatic scoring for answers to Arabic test questions. Computer Speech and Language, 28(4), 833857.

https://doi.org/10.1016/j.csl.2013.10. 005

Hayatin, N. (2015). Sistem Penilaian Jawaban Essay Otomatis Berdasarkan Nilai Kedekatan Kalimat. Seminar Teknologi Dan Rekayasa (SENTRA), October, 169-172.

Pramukantoro, E. S. (2016). Sistem penilaian otomatis jawaban. Jurnal Teknologi Informasi Dan Ilmu Komputer (JTIIK), 3(4), 248-252.

Pramukantoro, E. S., \& Fauzi, M. A. (2017). Comparative analysis of string similarity and corpus-based similarity for automatic essay scoring system on e-learning gamification. 2016 International Conference on Advanced Computer Science and Information Systems, ICACSIS 2016, 149-155.

https://doi.org/10.1109/ICACSIS.201 6.7872785

Prastowo, B. N., Riasetiawan, M., Herwanto, G. B., Sari, Y., Busthoni, I. A., Hidayatulloh, I., \& Adji, T. B. (2018). A Proposed Framework for Essay Answer Processing based on Computational. Proceeding Book of 1 st International Conference on Educational Assessment and Policy, 2 , 54-58. https://doi.org/10.26499/iceap.v2i1.9

6

Rinartha, K. (2017). Pemodelan Penilaian Essay Otomatis Secara Realtime Menggunakan Kombinasi Text Stemming Dan Cosine Similarity. 322-327.

Ruslan, Gunawan, \& Suhatati, T. (2018). Sistem Penilaian Otomatis Jawaban Esai Menggunakan Metode GLSA. Seminar Nasional Aplikasi Teknologi Informasi (SNATi) 2018, 6-15.

Susongko, P. (2013). Perbandingan Keefektifan Bentuk Tes Uraian dan Teslet dengan Penerapan Graded Response Model (GRM). Jurnal Penelitian Dan Evaluasi Pendidikan, 14(2), 269-288. https://doi.org/10.21831/pep.v14i2.10 82 